EL DINAR: Jurnal Keuangan dan Perbankan Syariah

Volume 6 , No. 1, Tahun 2018

P ISSN: 2339-2797; E ISSN: 2622-0083

\title{
PENGARUH PEMBIAYAAN MURABAHAH DAN MUSYARAKAH MELALUI KREDIT BERMASALAH TERHADAP LIKUIDITAS BANK UMUM SYARIAH
}

\author{
Sayyida Islamiya Laksmi Puteri \\ Universitas Islam Negeri Maulana Malik Ibrahim Malang \\ islamiahp26@gmail.com \\ Nihayatu Aslamatis Solekah \\ Universitas Islam Negeri Maulana Malik Ibrahim Malang \\ nihayatuaslamatiss@yahoo.co.id
}

\section{Abstract}

One of the causes of bankruptcy is not due to losess incurred but due to the inability to maintain cashflow availability. This study aims to determine the direct relationship of murabahah and musyarakah financing to Islamic bank liquidity through the NPF ratio. This study is descriptive quantitative study using path analysis and purposive sampling to determine the sample. The results of this study indicate that murabahah financing has no effect on NPF but effect the liquidity of Islamic bank. On the contrary, for musyarakah financing affecting NPF but not for liquidity of Islamic bank. It can be implied that due to differences in risk coverage of the two contract (murabahah financing dan musyarakah financing) where murabahah financing the level of risk that may arise will be more borne by the recipient of the financing. This contrasts with the musyarakah financing agreement where the risk Non performing loan can be minimized by sharing the risk in musyarakah financing.However, its relationship with bank liquidity, in fact murabahah financing provides a large contribution considering that islamic bank get certainty about the profit ratio of this financing agreement. As for musyarakah financing, Islamic bank liquidity actually decreases due to uncertainty in the profit sharing ratio it receives. From the result of the intervening test, NPF proxied by the ratio of NPF of Islamic banks did not mediate murabahah financing and musyarakah financing to Islamic bank liquidity.

Key words: Murabahah Financing; Musyarakah Financing; Liquidity; Non Performing Financing 
Sayyida Islamiya Laksmi Puteri: Pengaruh Pembiayaan Murabahah

Abstrak

Salah satu penyebab terjadinya kebankrutan bank bukanlah dikarenakan kerugian yang ditanggungnya melainkan dikarenakan ketidakmampuan menjaga ketersediaan cashflownya. Studi ini bertujuan untuk mengetahui hubungan langsung pembiayaan murobahah dan musyarakah terhadap likuiditas bank syariah melalui rasio NPF. Studi ini merupakan studi kuantitatif deskriptif dengan menggunakan analisis path dan purposive sampling sebagai metode penentuan samplenya. Hasil penelitian ini menunjukkan bahwa pembiayaan murobahah tidak berpengaruh terhadap NPF namun berpengaruh terhadap likuiditas bank syariah. Kebalikannya, untuk pembiayaan musyarakah berpengaruh terhadap NPF namun tidak terhadap likuditas Hasi ini bisa diimplikasikan bahwa dikarenakan perbedaan pertanggungan resiko dari dua akad tersebut dimana pembiayaan murobahah tingkat resiko yang mungkin muncul akan lebih banyak ditanggung oleh penerima pembiayaan tersebut. Hal ini bertolak belakang dengan akad pembiayaan musyarakah dimana resiko kredit macet bisa diminimalisir dengan pembagian resiko pada akad ini. Namun hubungannya dengan likuiditas bank justru pembiayaan murobahah memberikan kontribusi yang besar mengingat bank mendapatkan kepastian nisbah keuntungan dari akad pembiayaan ini. Sedangkan untuk pembiayaan musyarakah, likuiditas bank justru menjadi berkurang dikarenakan ketidakpastian nisbah bagi hasil yang diterimanya. Dari hasil uji mediasi NPF yang diproksikan dengan rasio NPF bank syariah tidak memediasi pembiayaan murabahah dan pembiayaan musyarakah terhadap likuiditas bank syariah.Kata kunci:

Kata kunci: Pembiayaan Murabahah; Pembiayaan Musyarakah; Likuiditas; Tingkat Kredit Macet

\section{PENDAHULUAN}

Dalam peraturan Bank Indonesia 15/7/PBI/2013, batas rasio likiuditas apabila dilihat dari nilai FDR adalah 78\% sebagai batas bawah sedangkan 92\% sebagai batas atas sehingga apabila suatu likuiditas melewati 98\% maka tingkat likuiditas tersebut tidak sehat seperti yang terjadi pada rasio likuiditas bank umum syariah tahun 2013 yang mencapai 100,32\%. Kemudian pada tahun 2014 tingkat rasio bank umum syariah menurun menjadi 86,66\% dan meningkat kembali menjadi 88,03\% pada tahun 2015 .

Tinggi rendahnya rasio likuiditas juga dapat dikarenakan aktiva suatu bank tersebut.Pada umumnya bank yang memiliki rasio likuiditas 
Sayyida Islamiya Laksmi Puteri: Pengaruh Pembiayaan Murabahah

tinggi aktiva jangka pendek lebih besar dibandingkan aktiva jangka panjang.Begitu juga sebaliknya, bank yang memiliki rasio likuiditas rendah porsi aktiva jangka panjangnya lebih besar daripada aktiva jangka pendek (Taswan, 2007).Kemudian penyebab lain tinggi rendahnya rasio likuiditas suatu bank dapat dikarenakan bank memberikan pembiayaan kepada masyarakat yang membuat profitabilitas bank tersebut tinggi namun likuiditas rendah sedangkan menahan dana yang dimiliki membuat rasio likuiditas bank tersebut rendah (Hidayati, 2014).

Ramadhani (2015) dalam penelitiannya menyatakan bahwa pembiayaan musyarakah tidak berpengaruh terhadap rasio likuiditas sedangkan menurut Ramdhani (2012) dalam penelitiannya menyatakan bahwa pembiayaan murabahah memiliki pengaruh terhadap rasio likuiditas. Ekanto (2013) menyatakan pembiayaan murabahah, ijarah atau qard memiliki pengaruh negatif terhadap Non Performing Financing (NPF) sedangkan pembiayaan musyarakah memiliki pengaruh yang tidak signifikan. Selanjutnya Laili (2015) menyatakan bahwa Non Performing Financing (NPF) tidak memberikan efek secara signifikan terhadap likuiditas bank syariah. Hal tersebut berbanding terbalik dengan hasil penelitian Hidayati (2014) yang menyatakan bahwa Non Performing Financing (NPF) memiliki hubungan yang signifikan terhadap likuiditas.

Penelitian ini bertujuan untuk mengetahui hubungan secara langsung maupun tidak langsung antara pembiayaan murabahah dan pembiayaan musyarakah melalui Non Performing Financing (NPF) terhadap likuiditas bank umum syariah.

\section{TINJAUAN PUSTAKA}

Pembiayaan murabahah merupakan model pembiayaan yang disalurkan oleh perbankan diqiyaskan seperti akad jual beli barang dan harus disebutkan dengan jelas jenis barang dan harganya oleh penjual barang tersebut. Kemudian penjual mensyaratkan laba atau keuntungan dalam jumlah tertentu atas barang tersebut yang disepakati penjual dan pembeli (Muhammad, 2009) 
Sayyida Islamiya Laksmi Puteri: Pengaruh Pembiayaan Murabahah

Pembiayaan musyarakah adalah salah satu akad ijarah (for profit transaction) yang mana merupakan bentuk pembiayaan yang menggunakan akad kerjasama antara dua pihak atau lebih untuk suatu usaha dimana setiap pihak baik pihak bank maupun penerima pembiayaan memberikan konstribusi dana yang mana keuntungan dan risiko ditanggung bersama sesuai kesepakatan (Muslich, 2010).

Menurut Mulyono (2002) Non Performing Financing (NPF) merupakan ukuran yang digunakan untuk melihat apakah terjadi pembiayaan bermasalah dalam manajemen suatu bank. Kemampuan kolektibilitas sebuah bank dalam mengumpulkan kembali pembiayaan yang telah disalurkan dapat ditunjukan oleh rasio Non Performing Financing dimana dapat dihitung menggunakan rumus :

$$
\text { Rasio NPF }=\frac{\text { Pembiayaan bermasalah }}{\text { Total Pembiayaan }} \times 100 \%
$$

Pengertian likuiditas untuk bank berbeda dengan pengertian likuiditas perusahaan non-bank. Likuiditas bank adalah kemampuan bank dalam memenuhi kebutuhan masyarakat berupa kredit dan memenuhi kemungkinan penarikan deposito atau simpanan oleh nasabah (Taswan, 2007). Likuiditas bank dapat diukur menggunakan Financing to Deposit Ratio (FDR) dengan rumus (Muhammad, 2009) :

$$
F D R=\frac{\text { Total Pembiayaan }}{\text { Dana Pihak Ketiga }} \times 100 \%
$$

\section{METODE PENELITIAN}

Penelitian ini menggunakan pendekatan kuantitatif dengan metode deskriptif. Penelitian ini dilakukan pada bank umum syariah di Indonesia yang memenuhi kriteria menjadi sampel serta laporan keuangan yang diterbitkan oleh situs Bank Indonesia dan annual report dari masing-masing bank umum syariah tahun 2013 - 2015.

Populasi dalam penelitian ini adalah seluruh bank umum syariah yang ada di Indonesia. Sampel merupakan sebagian populasi yang secara representatif mampu mewakili populasinya (Sabar, 2007). Bank Victoria Syariah, BRISyariah, Maybank Syariah, Bank Mega Syariah, serta BJB Syariah merupakan sampel yang memenuhi kriteria dalam penelitian ini. 
Sayyida Islamiya Laksmi Puteri: Pengaruh Pembiayaan Murabahah

\section{Analisis Jalur}

Analisis jalur adalah perluasan dari analisis regresi berganda yang digunakan untuk menaksir hubungan kausalitas antar variabel yang telah ditetapkan sebelumnya. Analisis jalur tidak dapat digunakan untuk mengkonfirmasi atau menolak hipotesis kausalitas imajiner akan tetapi analisis jalur dapat menentukan pola hubungan antara tiga variabel atau lebih (Ghozali, 2016).

\section{HASIL DAN PEMBAHASAN}

Terdapat beberapa langkah dalam analisis jalur yaitu merancang model berdasarkan konsep teori dan pemeriksaan terhadap asumsi yang melandasi (Aisyah, 2010).

\section{Hasil uji hipotesis pembiayaan murabahah $\left(X_{1}\right)$ dan pembiayaan musyarakah $\left(\mathrm{X}_{2}\right)$ terhadap NPF $(\mathrm{Z})$}

Tabel 1. Hasil Analisis Regresi Pembiayaan Murabahah $\left(X_{1}\right)$ dan Pembiayaan Musyarakah $\left(\mathrm{X}_{2}\right)$ Terhadap NPF $(\mathrm{Z})$

\begin{tabular}{lccc}
\multicolumn{1}{c}{ Variabel Bebas } & $\mathrm{T}$ & $\begin{array}{c}\text { Unstandardized } \\
\text { Coef B }\end{array}$ & Sig. \\
\hline Constanta & $-1,080$ & $-0,085$ & 0,285 \\
\hline Pembiayaan Murabahah $\left(\mathrm{X}_{1}\right)$ & 0,756 & 0,002 & 0,453 \\
\hline Pembiayaan Musyarakah $\left(\mathrm{X}_{2}\right)$ & 2,168 & 0,002 & 0,034 \\
\hline
\end{tabular}

Variabel Terikat $=$ Rasio $N P F$

$R=0,364 ; R^{2}=0,133 S_{e}=0,130$

Sumber: SPSS, data diolah 2017.

Dari tabel diatas dapat diperoleh model persamaan pertama sebagai berikut :

$\mathrm{Z}=-0,085+0,002 \mathrm{X}_{1}+0,002 \mathrm{X}_{2}$

$\mathrm{R}^{2}=0,133$ berarti variabel pembiayaan murabahah dan pembiayaan musyarakah dapat menjelaskan $13,3 \%$ variabel NPF.

Dari tabel hasil regresi diatas pembiayaan murobahah berkorelasi positif terhadap NPF, sesuai dengan nilai Beta (B) yang memiliki tanda posisitf. Untuk pembiayaan murabahah nilai signifikansinya 0.453 lebih besar dari 0.05 artinya pembiayaan murabahah tidak berpengaruh terhadap NPF. Dalam Kasus perbankan syariah ini banyaknya 
Sayyida Islamiya Laksmi Puteri: Pengaruh Pembiayaan Murabahah

pembiayaan murabahah yang diberikan tidak mempengaruhi peningkatan rasio NPF. Menurut Kuncoro (2002) pembiayaan bermasalah yang menggunakan akad pembiayaan murabahah dapat disebabakan oleh faktor eksternal dan faktor internal. Untuk faktor eksternal dapat berupa bencana alam atau adanya perubahan kebijakan pemerintah pada sektor riil, sedangkan untuk faktor internal seperti kelalaian pihak bank atau nasabah penerima pembiayaan tersebut.

Hasil dalam penelitian ini menolak $\mathrm{H}_{1}$ yang berarti bahwa pembiayaan murabahah tidak berpengaruh terhadap NPF. Hasil uji hipotesa dalam penelitian ini mendukung penelitian Kinasih (2013) dan bertolak belakang dengan hasil penelitian Ekanto (2013) yang menyatakan bahwa pembiayaan murabahah memiliki pengaruh yang signifikan terhadap NPF.

Sedangkan untuk pembiayaan musyarakah nilai signifikansinya 0.034 lebih kecil dari 0.05 artinya pembiayaan musyarakah berpengaruh terhadap NPF. Artinya pembiayaan musyarakah memiliki hubungan terhadap peningkatan rasio NPFpada perbankan syariah di Indonesia. Penelitian ini menerima uji hipotesa $\mathrm{H}_{2}$ yang menyatakan bahwa pembiayaan musyarakah berpengaruh terhadap rasio NPF. Hasil Uji Hipotesa ini mendukung penelitian Kinasih (2013) dan berbanding terbalik dengan penelitian Ekanto (2013) yang menyatakan bahwa pembiayaan musyarakah tidak memiliki pengaruh terhadap NPF.

\section{Hasil uji hipotesis pembiayaan murabahah $\left(\mathrm{X}_{1}\right)$, pembiayaan musyarakah $\left(\mathrm{X}_{2}\right)$ dan NPF $(\mathrm{Z})$ terhadap likuiditas $(\mathrm{Y})$}

Tabel 2. Hasil Analisis Regresi Pembiayaan Murabahah ( $\left.X_{1}\right)$ dan Pembiayaan Musyarakah $\left(\mathrm{X}_{2}\right)$, dan NPF (Z)Terhadap Rasio Likuiditas (Y)

\begin{tabular}{lccc}
\multicolumn{1}{c}{ Variabel Bebas } & $\mathrm{T}$ & $\begin{array}{c}\text { Unstandardized } \\
\text { Coef B }\end{array}$ & Sig. \\
\hline Constanta & 8,750 & 13,549 & 0,000 \\
\hline Pembiayaan Murabahah $\left(\mathrm{X}_{1}\right)$ & $-7,482$ & $-0,432$ & 0,000 \\
\hline Pembiayaan Musyarakah $\left(\mathrm{X}_{2}\right)$ & 0,503 & 0,009 & 0,617 \\
\hline NPF $(\mathrm{Z})$ & 0,026 & 0,066 & 0,980 \\
\hline
\end{tabular}

Variabel Terikat $=$ Rasio Likuiditas

$R=0,741 ; R^{2}=0,548 S_{e}=0,253$

Sumber: SPSS, data diolah 2017. 
Sayyida Islamiya Laksmi Puteri: Pengaruh Pembiayaan Murabahah

Dari tabel diatas dapat diperoleh model persamaan sebagai berikut :

$\mathrm{Y}=13,549-0,432 \mathrm{X}_{1}+0,009 \mathrm{X}_{2}+0,066 \mathrm{Z}$

$\mathrm{R}^{2}=0,548$ berarti variabel pembiayaan murabahah, pembiayaan musyarakah dan NPF menjelaskan 54,8\% variabel likuiditas.

Adapun hasil perhitungan koefisien path adalah sebagai berikut:

PTL $(X-Y)=P_{1} \times P_{2}$

PTL $(X-Y)=(0,002+0,002) \times 0,066=0,000264$

Keterangan:

PTL $(\mathrm{X}-\mathrm{Y})=$ Pengaruh tidak langsung pembiayaan murabahah $\left(\mathrm{X}_{1}\right)$ dan pembiayaan musyarakah $\mathrm{X}_{2}$ terhadap likuiditas $(\mathrm{Y})$

$\mathrm{P}_{1} \quad=$ Pengaruh langsung Pembiayaan murabahah $\left(\mathrm{X}_{1}\right)$ dan pembiayaan musyarakah $\left(\mathrm{X}_{2}\right)$ terhadap rasio $\mathrm{NPF}(\mathrm{Z})$

$\mathrm{P}_{2} \quad=$ Pengaruh rasio NPF $(\mathrm{Z})$ terhadap likuiditas $(\mathrm{Y})$

Berdasarkan hasil pengujian hipotesis tersebut, nilai Beta yang negatif menunjukan bahwa secara parsial pembiayaaan murabahah memiliki hubungan negatif terhadap likuiditas. Dilihat dari nilai signifikansi 0.00 dan lebih kecil dari 0.05 maka dapat diartikan bahwa pembiayaan murabahah memiliki pengaruh yang signifikan. Hasil uji hipotesa ini dapat diimplikasikan bahwa pembiayaan murabahah yang disalurkan mempengaruhi penurunan likuiditas bank syariah. Hasil uji hipotesa ini menerima $\mathrm{H}_{3}$ bahwa pembiayaan murabahah mempengaruhi likuiditas perbankan syariah. Hasil uji hipotesa ini mendukung hasil penelitian Ramdhani (2012). Namun hasil ini berbeda dengan hasil penelitian Adie (2010) yang menyatakan bahwa pembiayaan murabahah tidak berpengaruh terhadap rasio likuiditas bank syariah.

Berdasarkan nilai beta, hasil pengujian hipotesis menunjukan bahwa pembiayaan musyarakah memiliki hubungan positif dengan likuiditas. Berdasarkan nilai signifikansi, likuiditas tidak dipengaruhi oleh pembiayaan musyarakah yang ditunjukan oleh nilai signifikansi lebih besar dari 0,05 yaitu 0,617. Artinya, banyaknya pembiayaan yang diberikan tidak mempengaruhi besar kecilnya rasio likuiditas suatu bank. Penelitian ini menolak $\mathrm{H}_{4}$ yang berarti likuiditas tidak dipengaruhi 
Sayyida Islamiya Laksmi Puteri: Pengaruh Pembiayaan Murabahah

oleh pembiayaan musyarakah. Hasil uji hipotesa ini sesuai dengan hasil penelitian Ramadhani (2015) namun tidak sesuai dengan hasil penelitian Afkar (2011) yang menyatakan bahwa likuiditas dipengaruhi oleh pembiayaan musyarakah.

Berdasarkan nilai Beta hasil pengujian hipotesis secara parsial menunjukan bahwa NPF memiliki hubungan positif terhadap likuiditas. Berdasarkan nilai signifikansi NPF tidak mempengaruhi likuiditas perbankan syariah dengan nilai signifikansi lebih besar dari 0,05 yaitu 0,980 . Artinya, tingkat rasio NPF tidak mempengaruhi likuiditas bank syariah. Penelitian ini menolak $\mathrm{H}_{5}$ bahwa rasio NPF tidak berpengaruh terhadap likuiditas. Hasil uji hipotesa ini sesuai dengan hasil penelitianHidayati (2014) namun berbeda dengan hasil penelitian Utomo (2008) yang menyebutkan bahwa NPF tidak memiliki pengaruh terhadap likuiditas. Hal ini disebabkan karena bank selalu berusaha menjaga tingkat likuiditas demi menjaga kepercayaan masyarakat terhadap bank tersebut.

Hasil Uji Pengaruh tidak langsung pembiayaan murabahah $\left(\mathrm{X}_{1}\right)$, pembiayaan musyarakah $\left(\mathrm{X}_{2}\right)$ terhadap likuiditas (Y) melaui NPF (Z)

Berdasarkan hasil regresi yang telah disebutkan di atas, dapat dihitung pengaruh tidak langsung pembiayaan murabahah $\left(\mathrm{X}_{1}\right)$, pembiayaan musyarakah $\left(\mathrm{X}_{2}\right)$ terhadap likuiditas $(\mathrm{Y})$ melaui NPF (Z) yang mana koefisien jalurnya dapat dilihat pada gambar berikut :

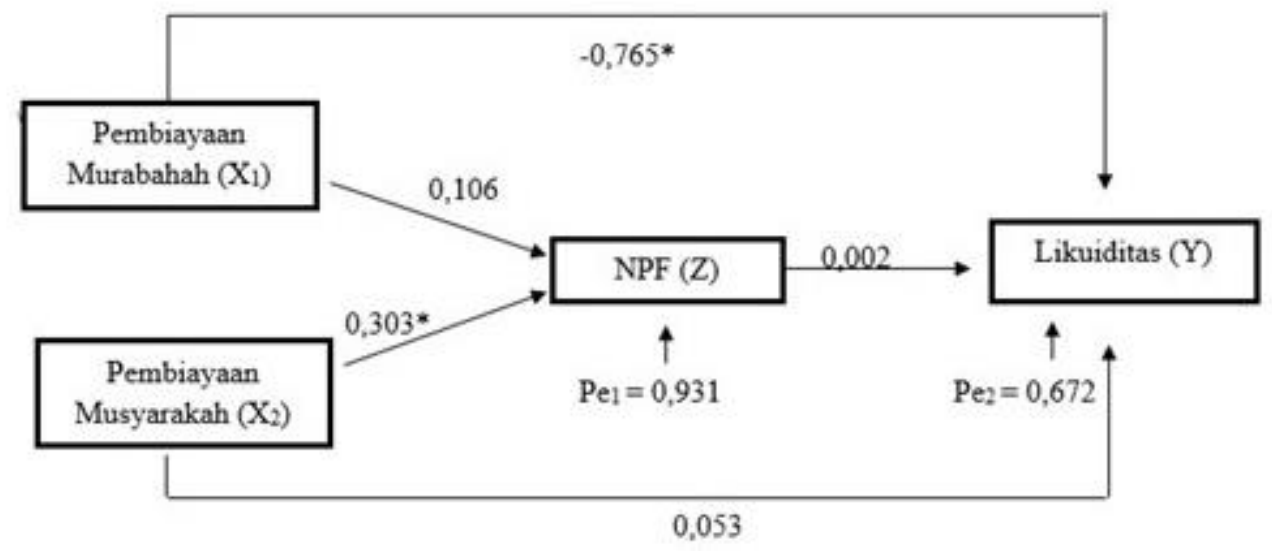

Gambar 1. Model Lintasan Pengaruh 
Sayyida Islamiya Laksmi Puteri: Pengaruh Pembiayaan Murabahah

Tabel 3. Pengaruh Langsung dan Pengaruh Tidak Langsung

\begin{tabular}{ccccc}
\hline Variabel Bebas & $\begin{array}{c}\text { Pengaruh } \\
\text { Langsung }\end{array}$ & Sig. & $\begin{array}{c}\text { Pengaruh Tidak } \\
\text { Langsung Melalui Z }\end{array}$ & Sig. \\
\hline $\mathrm{X}_{1}$ Terhadap Z & 0,106 & Tidak Sig. & $0,106 \times 0,002=0,000212$ & Tidak Sig. \\
\hline $\mathrm{X}_{2}$ Terhadap Z & 0,303 & Sig. & $0,303 \times 0,002=0,000606$ & Tidak Sig. \\
\hline Z Terhadap Y & 0066 & Tidak Sig. & Total $=0,000818$ & \\
\hline
\end{tabular}

Sumber: Data diolah 2017.

\section{Hasil Uji Validitas Model}

Berdasarkan model lintasan pengaruh tersebut dapat disusun analisis jalur. Pengaruh error pada persamaan pertama dan kedua adalah sebagai berikut:

$$
\begin{aligned}
& \mathrm{Pe}=\sqrt{1-\text { Rsquare }} \\
& \mathrm{Pe}_{1}=\sqrt{1-0,133}=0,931 \\
& \mathrm{Pe}_{2}=\sqrt{1-0,548}=0,672 \\
& \mathrm{Rm}^{2}=1-\mathrm{Pe}_{1}{ }^{2} \mathrm{Pe}_{2}{ }^{2} \\
& =1-\left(0,931^{2} \times 0,672^{2}\right) \\
& =0,609
\end{aligned}
$$

Jadi, model dapat menjelaskan total keragaman data sebesar 60,9\%.

\section{Hasil uji pengaruh pembiayaan murabahah $\left(X_{1}\right)$ dan pembiayaan musyarakah $\left(X_{2}\right)$ terhadap NPF $(Z)$}

Tabel 4. Nilai $t_{\text {hitung }}$ dan signifikansi variabel-variabel dari $X_{1}$ dan $X_{2}$ Terhadap $Z$

\begin{tabular}{cccc}
\hline Variabel Bebas & thitung $_{\text {Pig. }}$ & Sig. & Keterangan \\
\hline Pembiayaan Murabahah $\left(\mathrm{X}_{1}\right)$ & 0,756 & 0,453 & Tidak Signifikan \\
\hline Pembiayaan Musyarakah $\left(\mathrm{X}_{2}\right)$ & 2,168 & 0,034 & Signifikan \\
\hline
\end{tabular}

Sumber: Data diolah 2017. 
Sayyida Islamiya Laksmi Puteri: Pengaruh Pembiayaan Murabahah

\begin{tabular}{lllll}
\hline Hasil Uji pengaruh & pembiayaan murabahah $\left(\mathrm{X}_{1}\right)$ dan \\
pembiayaan musyarakah & $\left(\mathrm{X}_{2}\right)$ dan NPF $(\mathrm{Z})$ terhadap likuiditas $(\mathrm{Y})$
\end{tabular}

Tabel 5. Nilai $t_{\text {hitung }}$ dan signifikansi variabel-variabel dari $X_{1}$ dan $X_{2}$, dan Z Terhadap Y

\begin{tabular}{cccc}
\hline Variabel Bebas & thitung $_{\text {Sig. }}$ & Keterangan \\
\hline Pembiayaan Murabahah $\left(\mathrm{X}_{1}\right)$ & -7.482 & 0,000 & Signifikan \\
\hline Pembiayaan Musyarakah $\left(\mathrm{X}_{2}\right)$ & 0,503 & 0,617 & Tidak Signifikan \\
\hline Rasio NPF $(\mathrm{Z})$ & 0,026 & 0,980 & Tidak Signifikan \\
\hline
\end{tabular}

Sumber: Data diolah 2017.

\section{Hasil Uji Mediasi}

Perhitungan standard error dari koefisien indirect effect:

$$
\begin{aligned}
\mathrm{SP}_{1} \mathrm{P}_{5} & =\sqrt{\mathrm{P}_{5}{ }^{2} \mathrm{SP}_{1}{ }^{2}+\mathrm{P}_{1}{ }^{2} \mathrm{SP}_{5}{ }^{2}+\mathrm{SP}_{1}{ }^{2} \mathrm{SP}_{5}{ }^{2}} \\
& =\sqrt{\left(0,002^{2} x 0,003^{2}\right)+\left(0,106^{2} x 2,574^{2}\right)+\left(0,003^{2} x 2,574^{2}\right)} \\
& =\sqrt{0,000000000036+0,0744438483+0,0000596293}=0,27295 \\
\mathrm{SP}_{2} \mathrm{P}_{5} & =\sqrt{\mathrm{P}_{5}{ }^{2} \mathrm{SP}_{2}{ }^{2}+\mathrm{P}_{2}{ }^{2} \mathrm{SP}_{5}{ }^{2}+\mathrm{SP}_{2} 2 \mathrm{SP}_{5}{ }^{2}} \\
& =\sqrt{\left(0,002^{2} x 0,001^{2}\right)+\left(0,303^{2} x 2,574^{2}\right)+\left(0,001^{2} x 2,574^{2}\right)} \\
& =\sqrt{0,000000000004+0,6082783261+0,0000066255}=0,77993
\end{aligned}
$$

Nilai t statistic pengaruh mediasi dapat dihitung dari hasil $\mathrm{SP}_{1,2} \mathrm{P}_{5}$ di atas dengan rumus sebagi berikut:
$\mathrm{t}_{\mathrm{X} 1}=\frac{P_{1} P_{5}}{S P_{1} P_{5}}$
$\mathrm{t} \mathrm{X} 2 \quad=\frac{P_{2} P_{5}}{S P_{2} P_{5}}$
$=\frac{(0,106 \times 0,002)}{0,2729}$
$=\frac{(0,303 \times 0,002)}{0,7799}$
$=0,0007768413$
$=0,002642826$ 
Sayyida Islamiya Laksmi Puteri: Pengaruh Pembiayaan Murabahah

KESIMPULAN

1. Non Performing Financing (NPF) dipengaruhi oleh pembiayaan musyarakah namun tidak dipengaruhi oleh pembiayaan murabahah.

2. Likuiditas dipengaruhi oleh pembiayaan murabahah namun tidak dipengaruhi oleh pembiayaan musyarakah.

3. Likuiditas tidak dipengaruhi secara tidak langsung melalui NPF oleh pembiayaan murabahah dan pembiayaan musyarakah.

\section{DAFTAR PUSTAKA}

Adie, Thia Luthia. 2010. Analysis of Murabahah Financing Its Influence To Liquidition Level At PT. Bank Muamalat Indonesia, Tbk.

Afkar, Taudlikhul. 2011. Pengaruh Pembiayaan Modal Kerja, Pembiayaan Investasi, dan Pembiayaan Konsumsi Terhadap Likuiditas Perbankan Syariah Indonesia.

Aisyah, Esy Nur. 2010. Analisis Faktor-faktor Yang Mempengaruhi Kinerja Perusahaan (Studi Pada Lembaga BMT Maslahah Mursalah Lil Ummah di Pasuruan).Tesis (Tidak dipublikasikan). Pascasarjana Fakultas Ekonomi Universitas Brawijaya Malang

Ekanto, Aries Wahyu. 2013. Pengaruh Penyaluran Pembiayaan Yang Diberikan Terhadap Tingkat Kenaikan NPF Pada Perbankan Syariah

Ghozali, Imam. 2016. Aplikasi Analisis Multivariete Dengan Program IBM SPSS 23. Semarang: Badan Penerbit Universitas Diponegoro

Hidayati, Nur Laili. 2014. Pengaruh Pembiayaan Jual Beli, Pembiayaan

Bagi Hasil, Pembiayaan Sewa. Dan Rasio Non Performing Financing terhadap Likuiditas Bank Umum Syariah di Indonesia.

Kinasih, Septivia Wahyu dan Dodik Siswantoro. 2013. Analisis Faktor Determinn Tingkat Risiko Pembiayaan Bank Syariah Pada Tahun 2005-2012

Kuncoro, Mudrajad dan Suhardjono.2002. Manajemen Perbankan Teori dan Aplikasi. Yogyakarta: BPEE

Laili, Isyafatul Nur. 2015. Pengaruh CAR, Perputaran KAS, dan NPF Terhadap Likuiditas Bank Muamalat 
Sayyida Islamiya Laksmi Puteri: Pengaruh Pembiayaan Murabahah

Muhammad. 2009. Model-model Akad Pembiayaan di Bank Sharia. Yogyakarta: UII Pres

Mulyono, Teguh Pudjo. 2002. Analisa Laporan Keuangan Untuk

Perbankan. Jakarta: Djambatan

Muslich, Ahmad Wardi. 2010. Fiqh Muamalat. Jakarta: Amzah

Ramadhani, Aulia dan Imron Mawardi.2015. Pengaruh Pembiayaan

Mudharabah dan Musyarakah Terhadap Likuiditas Industri Bank

Syariah di Indonesia. [JESTT Vol. 2 No. 7] diakses tanggal 10

November 2016

Ramdhani, Indra. 2012. Pengaruh Pembiayaan Murabahah Terhadap

Likuiditas Bank (Studi Kasus pada PT. BPR Syariah Al-Wadiah Tasikmalaya)

Sabar, Rutoto. 2007. Pengantar Metodologi Penelitian. Kudus: FKIP Universitas Muria Kudus

Taswan. 2007. Manajemen Perbankan. Yogyakarta: UPP STIM YPKP

Utomo, Andi Priyo. 2008. Pengaruh NPL Terhadap Kinerja Keuangan

Bank Berdasarkan Rasio Likuiditas, Rasio Solvabilitas, dan Rasio

Profitabilitas pada PT. Bank Mandiri (Persero), TBK. Jakarta:

Repository Universitas Gunadarma 